\title{
Cartilage-protective effects of C-type natriuretic peptide over expression in K/BxN TCR arthritis model
}

\author{
Hulya Bukulmez ${ }^{4^{*}}$, Cynthia F Bartels ${ }^{1}$, Kabita Nanda ${ }^{3}$, Tariq M Haqqi ${ }^{2}$, Jean F Welter ${ }^{1}$ \\ From 2011 Pediatric Rheumatology Symposium sponsored by the American College of Rheumatology \\ Miami, FL, USA. 2-5 June 2011
}

\section{Purpose}

The c-type natriuretic peptide (CNP) signaling pathway is known as a major contributor to skeletal growth in children. CNP is produced and secreted by both growth plate and joint chondrocytes, and has a paracrine regulatory effect on cartilage tissue. CNP increases matrix production by chondrocytes and promotes their proliferation. In this study, we investigated whether over-expression of CNP in chondrocytes would be protective of joint cartilage degradation during chronic inflammatory arthritis in vivo.

\section{Methods}

We first developed transgenic mice that over-express CNP $\left(C N P^{\text {col2a1TG }}\right)$ in chondrocytes under the control of the collagen $2 \mathrm{a} 1$ promoter and enhancer. Then, we obtained $\mathrm{K} / \mathrm{BxN}$ TCR transgenic mice from a collaborator and analyzed both transgenic mice for their joint cartilage clinical and histologic findings over time. We crossed CNP ${ }^{\text {col2a1TG }}$ mouse with $\mathrm{K} / \mathrm{BxN}$ TCR transgenic mouse to produce mice with both $\mathrm{K} / \mathrm{BxN} \mathrm{TCR}$ and CNP $P^{\text {col2a1TG }}$ backgrounds. The degree of arthritis and cartilage damage in the offspring was analyzed using a clinical scoring system and two histological scoring systems. Differences between the scores were analyzed using the Student's t-test.

\section{Results}

Mice that carried the transgene for both $\mathrm{CNP}^{\text {col2a1TG }}$ and $\mathrm{K} / \mathrm{BxN}$ TCR showed less severe clinical and histologic arthritis findings in the joint cartilage compared to wild type littermates. Between the ages of 6-14 weeks, the average arthritis score of $\mathrm{K} / \mathrm{BxN} \mathrm{TCR}$ transgenic

${ }^{4}$ Skeletal Research Center and MetroHealth Medical Center, Case Western Reserve University, Cleveland, OH, USA

Full list of author information is available at the end of the article mice that over-expressed CNP was $4.37 \pm 1.38$ ( $\mathrm{n}=8)$, while the average arthritis score of $\mathrm{K} / \mathrm{BxN} \mathrm{TCR}$ arthritic mice of the same age was $8.66 \pm 3.26(\mathrm{n}=14),(\mathrm{p}<0.05)$. Histological staining and morphometry did not show any evidence of cartilage degradation in the joint cartilage of $\mathrm{CNP}^{\text {col2alTG }}$ mice. The knee and ankle cartilage of $\mathrm{CNP}^{\text {col2alTG }}$ mice was thick and showed increased proteoglycan content by Safranin-O staining. However, the double-transgenic offspring mice $\left(\mathrm{K} / \mathrm{BxN} / \mathrm{CNP}^{\mathrm{co}-}\right.$ 12a1TG) developed less cartilage damage and less chondrocyte disorganization while still developing inflammatory changes (pannus) in the synovium, similar to the $\mathrm{K} / \mathrm{BxN}$ TCR mice. We adapted the ICRS histological scoring system and gave scores to the knee joint cartilage of the 8 -week-old male mice. $\mathrm{K} / \mathrm{BxN}$ mice $(\mathrm{n}=7)$ scored significantly lower for both chondrocytic cell distribution (III) and chondrocyte matrix content (II) $(\mathrm{p}<0.001$ and $\mathrm{p}<0.05$, respectively) than the $(\mathrm{K} / \mathrm{BxN} /$ $\mathrm{CNP}^{\text {col2a1TG }}$ mice $(\mathrm{n}=12)$.

\section{Conclusion}

K/BxN TCR arthritic mice over-expressing CNP did not have joint cartilage damage due to chronic inflammation. We conclude that excess paracrine production of CNP in the joint cartilage of double-transgenic $\mathrm{K} / \mathrm{BxN} / \mathrm{CNP}^{\mathrm{co}-}$ 12a1TG arthritic mice was able to overcome the effects of pro-inflammatory cytokines on joint cartilage in vivo. CNP and the effector molecules of CNP signaling pathway may have therapeutic potential in protecting cartilage homeostasis during chronic inflammatory arthritis.

\section{Disclosure}

Hulya Bukulmez: None; Cynthia F. Bartels: None; Kabita Nanda: None; Tariq M. Haqqi: None; Jean F. Welter: None. 


\section{Author details}

${ }^{1}$ Case Western Reserve University, Cleveland, OH, USA. ${ }^{2}$ MetroHealth Medical Center, Case Western Reserve University, Cleveland, OH, USA. ${ }^{3}$ Rainbow Babies and Children, Cleveland, OH, USA. ${ }^{4}$ Skeletal Research Center and MetroHealth Medical Center, Case Western Reserve University, Cleveland, $\mathrm{OH}$, USA.

Published: 13 July 2012

doi:10.1186/1546-0096-10-S1-A109

Cite this article as: Bukulmez et al.: Cartilage-protective effects of C-type natriuretic peptide over expression in K/BxN TCR arthritis model.

Pediatric Rheumatology 2012 10(Suppl 1):A109.

Submit your next manuscript to BioMed Central and take full advantage of:

- Convenient online submission

- Thorough peer review

- No space constraints or color figure charges

- Immediate publication on acceptance

- Inclusion in PubMed, CAS, Scopus and Google Scholar

- Research which is freely available for redistribution

Submit your manuscript at www.biomedcentral.com/submit
C Biomed Central 